Abstracted/indexed in Academic Search Complete, Agroforestry Abstracts, Asia Journals Online, Bangladesh Journals Online, Biological Abstracts, BIOSIS Previews, CAB Abstracts, Current Abstracts, Directory of Open Access Journals, EMBASE/Excerpta Medica, Google Scholar, HINARI (WHO), International Pharmaceutical Abstracts, Open J-gate, Science Citation Index Expanded and Social Sciences Citation Index

ISSN: $1991-0088$

\title{
Cytotoxicity study of reaction products between isatin and furan
}

\author{
Md. Arifuzzaman, Rafiya Khan Kandahary and Md. Rabiul Islam
}

Department of Chemistry, Jahangirnagar University, Savar, Dhaka 1342, Bangladesh.

\begin{tabular}{|c|c|}
\hline \multicolumn{2}{|l|}{ Article Info } \\
\hline Received: & 14 April 2009 \\
\hline Accepted: & 23 April 2009 \\
\hline Available Online: & 24 April 2009 \\
\hline \multicolumn{2}{|c|}{ DOI: 10.3329/bjp.v4i2.2381 } \\
\hline \multicolumn{2}{|c|}{$\begin{array}{l}\text { Cite this article: } \\
\text { Arifuzzaman M, Kandahary RK, } \\
\text { Islam MR. Cytotoxicity study of } \\
\text { reaction products between isatin } \\
\text { and furan. Bangladesh J Pharma- } \\
\text { col. 2009; 4: 96-100. }\end{array}$} \\
\hline
\end{tabular}

\begin{abstract}
Isatin, 5-chloroisatin, 7-bromoisatin and 7-ethylisatin on treatment with furan in presence of diethylamine yield furan moiety inclusion products bis-diisatin [3,3'] furan, bis-[5,5'] dichlorodiisatin [3,3'] furan, bis-[7,7'] dibromodiisatin $\left[3,3^{\prime}\right]$ furan and bis-[7,7'] diethyldiisatin [3,3'] furan respectively in moderate yields. The cytotoxicity of these compounds was studied by the brine shrimp lethality bioassay and the Structure activity relationships (SAR) of these compounds has been discussed. The present study shows that the compound bis$\left[7,7^{\prime}\right]$ dibromodiisatin $\left[3,3^{\prime}\right]$ furan had pronounced cytotoxicity whereas compounds bis-[5,5'] dichlorodiisatin [3,3'] furan and bis-[7,7’] diethyldiisatin [3,3'] furan were moderately active. It is remarkable that the constituent, $\mathrm{Y}=-\mathrm{Br}$ at seven position in the benzene ring has greater activity than ethyl and chlorine atom.
\end{abstract}

\section{Introduction}

Isatin (indole-2,3-dione) (1a) being a biofunctional compound shows chemical activity at the keto group $(\mathrm{C}$ -3) and a large number of isatin derivatives have been synthesized which possess biological activity and pharmacological activity like fungicides (Chen and Rhodes, 1996), insecticides (Bahmaria and Deliwala, 1968), anti-cancer (Holla et al., 2000), antifungal properties (Islam et al., 1998). In continuation of our systematic studies (Islam et al., 2001) on isatin derivatives as potential cytotoxic agents, we extended our work on the reaction between isatin and thiophene (Hoque and Islam, 2008). Isatin reacted with thiophene in presence of conc. $\mathrm{H}_{2} \mathrm{SO}_{4}$ to afford a mixture of products having a single and two thiophene moiety inserted in two isatin molecules. So, we planned to investigate the reaction of isatin with furan and their cytotoxicity by brine shrimp lethality bioassay (Meyer et al., 1982; Solis et al., 1993).

\section{Materials and Methods}

All melting points are uncorrected and were recorded by thin disc method on a "Fischer Johns" electrothermal melting point apparatus. Thin layer chromato- graphy (TLC) was performed on silica gel $60 \mathrm{~F}_{254}$ as the coating substance. IR spectra were recorded in $\mathrm{KBr}$ disc on a FT-IR/200 spectrophotometer. ${ }^{1} \mathrm{H}$ NMR spectra were recorded on VXR $300 \mathrm{MHz}$ using $\mathrm{CDCl}_{3}$ solvent with TMS as internal standard.

The tested compound (Scheme 1) 2a, 2b, 2c and $\mathbf{2 d}$ were synthesized by following procedure. The products have been characterized with the help of spectral analysis from Japan (Okayama University).

\section{Preparation of Bis-diisatin [3,3'] furan (2a)}

To a solution of isatin $(0.5 \mathrm{~g}, 3.4 \mathrm{mmoL})$ in acetic acid $(30 \mathrm{~mL})$ at room temperature was added then furan $(3.5$ $\mathrm{mL})$ in presence of diethylamine $(12 \mathrm{~mL})$ under intensive stirring. The temperature was raised to $80^{\circ} \mathrm{C}$ and kept for $60 \mathrm{~min}$. The color of reaction mixture quickly changed from red to deep blue. Then the reaction mixture was stirred overnight at room temperature. After completion of the reaction distilled water $(40 \mathrm{~mL})$ was added and the products were extracted by $\mathrm{CHCl}_{3}$. The organic layer was washed with water $(2 \times 20)$ and dried over anhydrous $\mathrm{CaCl}_{2}$. The solvent on evaporation under reduced pressure gave a crystalline solid product (2a) having a yield of $80 \%(2.7 \mathrm{~g})$ and m.p. 90$91^{\circ} \mathrm{C}$. This product was found to be homogeneous on 


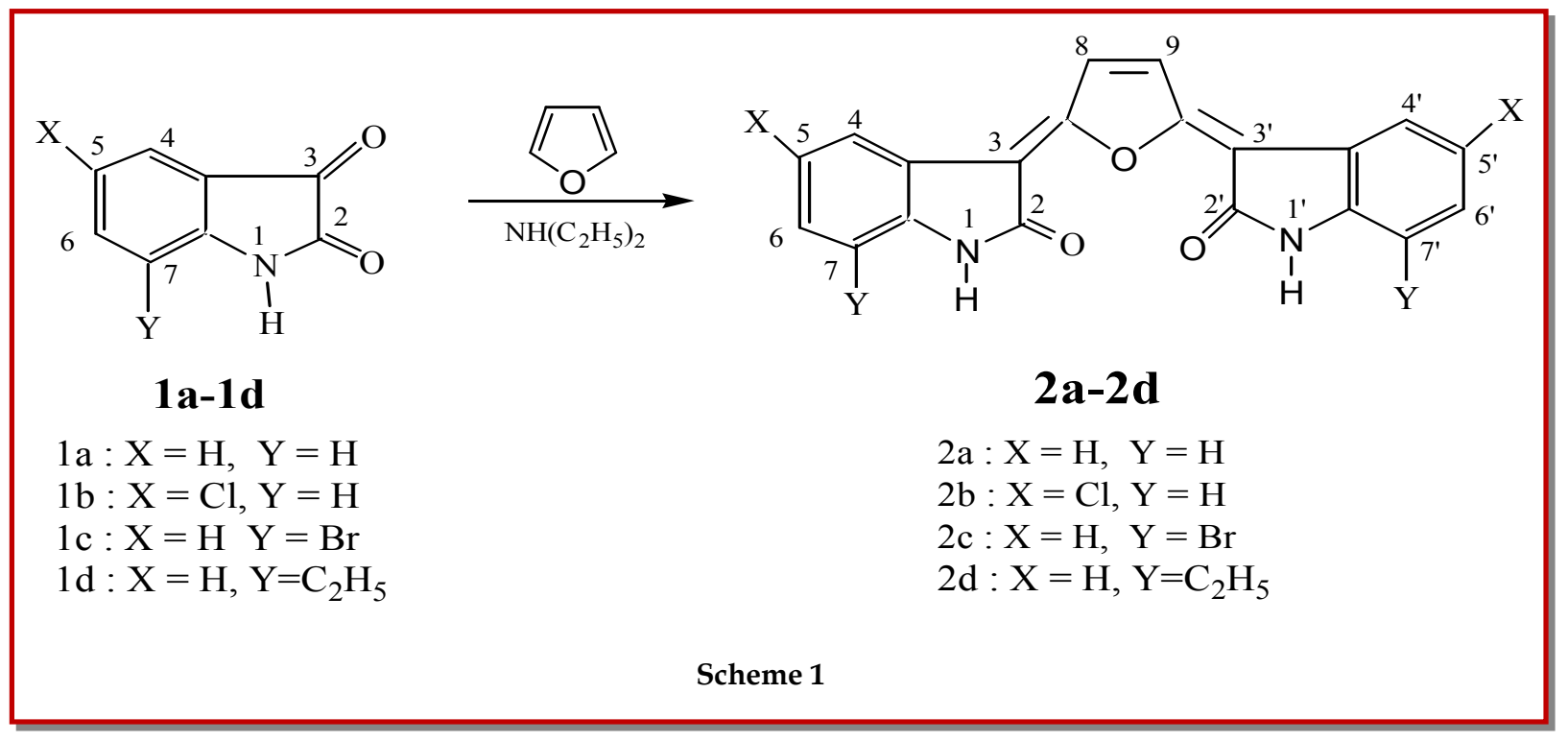<smiles>O=C1Nc2c(Br)cccc2C1=c1cc/c(=C2\C(=O)Nc3c(Br)cccc32)o1</smiles>

2c

$$
\mathrm{LC}_{50}=0.0005
$$<smiles>CCc1cccc2c1N[NH+]1C(=O)C2=c2ccc(o2)=C2C(=O)N(c3c(CC)cccc32)C1CC</smiles>

2d

$\mathrm{LC}_{50}=0.003$<smiles>O=C1NNc2ccc(Cl)cc2/C1=c1/cc/c(=C2\C(=O)Nc3ccc(Cl)cc32)o1</smiles>

2b

$\mathrm{LC}_{50}=0.003$<smiles></smiles>

2a

$\mathrm{LC}_{50}=0.011$

Scheme 2

silica gel TLC plate with $\mathrm{R}_{\mathrm{f}}=0.4$ (petrol ether: ethyl acetate $=1: 4$ ).

\section{Preparation of Bis-[5,5'] dichloro diisatin [3,3'] furan (2b)}

Similarly compound $\mathbf{2 b}$ was prepared from 5-chloroisatin $(3.3 \mathrm{~g}, 2.8 \mathrm{mmol})$ in acetic acid $(20 \mathrm{~mL})$ and furan $(2 \mathrm{~mL})$ in presence of diethylamine $(25 \mathrm{~mL})$. The usual work-up gave a crystalline solid product $(\mathbf{2 b})$ having a yield of $82 \%$ (3.7 g) and m.p. $95-96^{\circ} \mathrm{C}$. This product was found to be homogeneous on silica gel TLC plate with
$R_{\mathrm{f}}=0.4$ (petroleum ether: ethylacetate $=1: 4$ ).

Preparation of Bis-[7,7'] dibromo diisatin [3,3'] furan (2c)

Similarly compound $2 \mathrm{c}$ was prepared from 7bromoisatin $(0.2 \mathrm{~g}, 2.1 \mathrm{mmoL})$ in acetic acid $(20 \mathrm{~mL})$ and furan $(2 \mathrm{~mL})$ in presence of diethylamine $(10 \mathrm{~mL})$. The usual work-up gave a crystalline solid product (2c) having a yield of $85 \%(3.9 \mathrm{~g})$ and m.p. $96-97^{\circ} \mathrm{C}$. This product was found to be homogeneous on silica gel TLC plate with $R_{\mathrm{f}}=0.4$ (petroleum ether: ethylacetate $=$ $1: 4)$. 
<smiles>O=c1[nH][nH]c2c(Br)cccc12</smiles>

$2 \mathrm{c}$

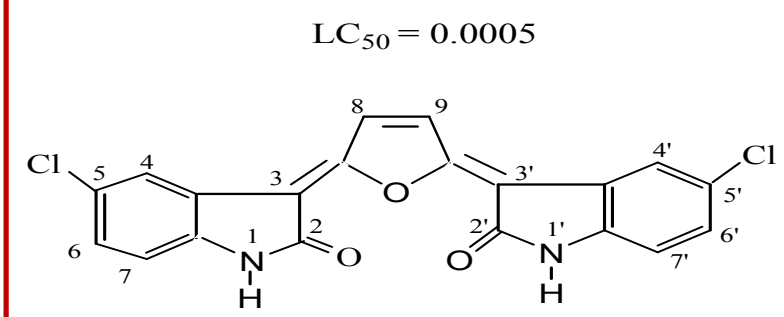

2b

$\mathrm{LC}_{50}=0.003$<smiles></smiles>

$2 \mathbf{a}$

$\mathrm{LC}_{50}=0.011$<smiles></smiles>

$\mathrm{LC}_{50}=1.25$<smiles>O=C1Nc2ccc(Cl)cc2C1=C1C=CC2=C3C(=O)NN(c4ccc(Cl)cc43)[SH]12</smiles>

$\mathrm{LC}_{50}=1.22$<smiles>O=C1Nc2ccccc2/C1=c1/cc/c(=C2\C(=O)Nc3ccccc32)s1</smiles>

$\mathrm{LC}_{50}=1.00$

\section{Scheme 3}

Preparation of Bis-[7,7'] diethyl disatin [3,3'] furan (2d)

Similarly compound $2 \mathrm{~d}$ was prepared from 7ethylisatin $(0.4 \mathrm{~g}, 2.1 \mathrm{mmoL})$ in acetic acid $(20 \mathrm{~mL})$ and furan $(2 \mathrm{~mL})$ in presence of diethylamine $(10 \mathrm{~mL})$. The usual work-up gave a brick red crystal-line solid product (2d) having a yield of $85 \%$ (3.9 g) and m.p. 93$94^{\circ} \mathrm{C}$. This product was found to be homogeneous on silica gel tlc. plate with $\mathrm{R}_{\mathrm{f}}=0.4$ (petroleum ether: ethyl acetate $=1: 4)$.

The cytotoxicity of the synthesized compounds was studied by brine shrimp lethality bioassay (Solis et al., 1993).

\section{Test animal}

Brine shrimps (Artemia salina) were used as test animal for the investigation of cytotoxicity.

\section{Hatching and maintenance of brine shrimp}

The preferred condition for brine shrimp (temperature $28-30^{\circ} \mathrm{C}$, salinity $30-35 \mathrm{ppt}, \mathrm{pH} 8-9$ and strong aeration) was established by mixing sodium chloride salts in water. After obtaining the desired condition, about one tea spoon of brine shrimp eggs was added to the beaker. After twelve hours hatching aggregated brine shrimp nauplii were collected in another beaker and rinsed with fresh water and applied for testing.

\section{Preparation of test sample}

For the cytotoxicity study, dimethylsulphoxide (DMSO) was used as solvent and the mortality of brine shrimp nauplii in this DMSO was almost zero. Different concentration $(150,100$ and $50 \mu \mathrm{g} / \mathrm{mL})$ of each test samples were prepared with DMSO. Then 10-12 brine shrimp nauplii were transferred to each test tube using a micro pipette.

\section{Counting of nauplii}

The numbers of survived nauplii in each test tube were counted. The percentage of mortality of brine shrimp was calculated for each sample that gives different mortality for different concentrations. An approximate linear correlation was observed when logarithm of concentration was plotted against percentage of mortality and the values of $\mathrm{LC}_{50}$ were calculated for each sample. The $\mathrm{LC}_{50}$ represents the concentration of a compound which will kill or inactive 50 percent of the test animal. $\mathrm{LC}_{50}$ is inversely proportional to the toxicity of a compound, i.e. the lower the $\mathrm{LC}_{50}$ the higher the toxicity. 


\section{Results}

The structures of the synthesized compounds were analyzed by the spectroscopic data. The product $2 \mathrm{a}$ was obtained crystalline solid having a yield of $80 \%$ after purification. IR (KBr): v (cm-1): 3500 (br, vO-H), 3400 (br, vN-H), 3000 (sh, vC-H, aromatic), 1715(vC=O, lactam), $1690(\mathrm{C}=\mathrm{N}), 1575,1450 \mathrm{~cm}^{-1}$ (vC=C, aromatic). 1H-NMR $\left(\mathrm{CDCl}_{3}\right)$ spectrum: $\delta_{\mathrm{H}}(\mathrm{ppm}): \delta 7.40(\mathrm{~d}, 2 \mathrm{H}$, $\left.\mathrm{H}_{4 / 4^{\prime}}\right), \delta 6.90(\mathrm{~s}, 2 \mathrm{H}, 2 \mathrm{~N}-\mathrm{H}), \delta$ 6.40-6.50 (m, 6H, $\mathrm{H}_{5 / 5^{\prime}}$, $\left.\mathrm{H}_{6 / 6^{\prime}}, \mathrm{H}_{7 / 7^{\prime}}\right), \delta 5.50\left(\mathrm{~s}, 2 \mathrm{H}, \mathrm{H}_{8,9}\right.$ ); Elemental analysis; the molecular formula of the compound $2 \mathrm{a}$ is $\mathrm{C}_{20} \mathrm{H}_{12} \mathrm{~N}_{2} \mathrm{O}_{3}$. The found value of $\mathrm{C}=74.10, \mathrm{H}=3.70, \mathrm{~N}=8.51$ whereas the calculated value is $\mathrm{C}=73.17, \mathrm{H}=3.60, \mathrm{~N}=8.50$. From the microanalysis result the rest $13.7 \%$ is due to oxygen atom. On the other hand, the actual calculation \% $\mathrm{O}=14.7$. So, the result clearly shows that one furan ring is condensed with two isatin molecules.

The product $\mathbf{2 b}$ was obtained as crystalline solid having a yield of $82 \%$ after purification. IR (KBr): $v\left(\mathrm{~cm}^{-1}\right): 3500$ (br, vO-H), 3400 (br, vN-H), 3000 (sh, vC-H, aromatic), $1715(\mathrm{vC}=\mathrm{O}$, lactam $), 1690(\mathrm{C}=\mathrm{N}), 1575,1450 \mathrm{~cm}^{-1}$ (vC=C, aromatic). ${ }^{1} \mathrm{H}-\mathrm{NMR}\left(\mathrm{CDCl}_{3}\right)$ spectrum: $\delta_{\mathrm{H}}$ (ppm): $\delta 7.40$ (d, 2H, H4/4), $\delta 7.00(\mathrm{~s}, 2 \mathrm{H}, 2 \mathrm{~N}-\mathrm{H}), \delta 6.40-$ $6.50\left(\mathrm{~m}, 4 \mathrm{H}, \mathrm{H}_{6 / 6}, \mathrm{H}_{7 / 7}\right), \delta 4.90\left(\mathrm{~s}, 2 \mathrm{H}, \mathrm{H}_{8,9}\right)$; Elemental analysis; the molecular formula of the compound $2 \mathrm{~b}$ is $\mathrm{C}_{20} \mathrm{H}_{10} \mathrm{~N}_{2} \mathrm{O}_{3} \mathrm{Cl}_{2}$. The found value of $\mathrm{C}=61.31, \mathrm{H}=2.52$, $\mathrm{N}=7.10$ whereas the calculated value is $\mathrm{C}=60.30, \mathrm{H}=$ 2.52, N=7.0. From the microanalysis result the rest $29.07 \%$ is due to oxygen and chlorine atom. On the other hand, the actual calculation of $\% \mathrm{O}=12.1$ and $\%$ $\mathrm{Cl}=18.1$. The total, $\% \mathrm{O}+\% \mathrm{Cl}=30.1$. The result is consistent with the structure of the compound.

The product $2 \mathrm{c}$ was obtained as crystalline solid having a yield of $85 \%$ after purification. IR $(\mathrm{KBr}): \mathrm{v}\left(\mathrm{cm}^{-1}\right): 3500$ (br, vO-H), 3400 (br, vN-H), 3000 (sh, vC-H, aromatic), $1715(\mathrm{vC}=\mathrm{O}$, lactam $), 1690(\mathrm{C}=\mathrm{N}), 1575,1450 \mathrm{~cm}^{-1}$ (vC=C, aromatic). ${ }^{1} \mathrm{H}-\mathrm{NMR}\left(\mathrm{CDCl}_{3}\right)$ spectrum: $\delta_{\mathrm{H}}$ (ppm): $\delta 7.40$ (d, 2H, $\left.\mathrm{H}_{6 / 6^{\prime}}\right), \delta 6.80(\mathrm{~s}, 2 \mathrm{H}, 2 \mathrm{~N}-\mathrm{H}), \delta 6.30-$ $6.40\left(\mathrm{~m}, 4 \mathrm{H}, \mathrm{H}_{4 / 4^{\prime}}, \mathrm{H}_{5 / 5^{\prime}}\right), \delta 4.80\left(\mathrm{~s}, 2 \mathrm{H}, \mathrm{H}_{8,9}\right)$; Elemental analysis: the molecular formula of the compound $2 \mathrm{c}$ is $\mathrm{C}_{20} \mathrm{H}_{10} \mathrm{~N}_{2} \mathrm{O}_{3} \mathrm{Br}_{2}$. The found value of $\mathrm{C}=49.38, \mathrm{H}=2.05, \mathrm{~N}$ $=5.79$ whereas the calculated value is $\mathrm{C}=49.37, \mathrm{H}=2.05$, $\mathrm{N}=5.79$. From the microanalysis result the rest $42.8 \%$ is due to oxygen and bromine atom. On the other hand, the actual calculation of $\% \mathrm{O}=9.9$ and $\% \mathrm{Br}=32.9$. The total, $\% \mathrm{O}+\% \mathrm{Br}=42.8$. So, the result clearly shows that one furan ring is condensed with two 7-bromoisatin molecules.

The product $2 \mathrm{~d}$ was obtained as crystalline solid having a yield of $85 \%$ after purification. IR $(\mathrm{KBr}): \mathrm{v}\left(\mathrm{cm}^{-1}\right): 3500$ (br, vO-H), 3400 (br, vN-H), 3000 (sh, vC-H, aromatic), 1715 (vC=O, lactam), $1690(\mathrm{C}=\mathrm{N}), 1575,1450 \mathrm{~cm}^{-1}$ (vC=C, aromatic). ${ }^{1} \mathrm{H}-\mathrm{NMR}\left(\mathrm{CDCl}_{3}\right)$ spectrum: $\delta_{\mathrm{H}}$ (ppm): $\delta 7.40\left(\mathrm{~d}, 2 \mathrm{H}, \mathrm{H}_{6 / 6^{\prime}}\right), \delta 7.00(\mathrm{~s}, 2 \mathrm{H}, 2 \mathrm{~N}-\mathrm{H}), \delta 6.30-$ $6.40\left(\mathrm{~m}, 4 \mathrm{H}_{1} \mathrm{H}_{4 / 4^{\prime}}, \mathrm{H}_{5 / 5^{\prime}}\right), \delta 5.5\left(\mathrm{~s}, 2 \mathrm{H}, \mathrm{H}_{8,9}\right), \delta$ 1.6-1.5 (q,

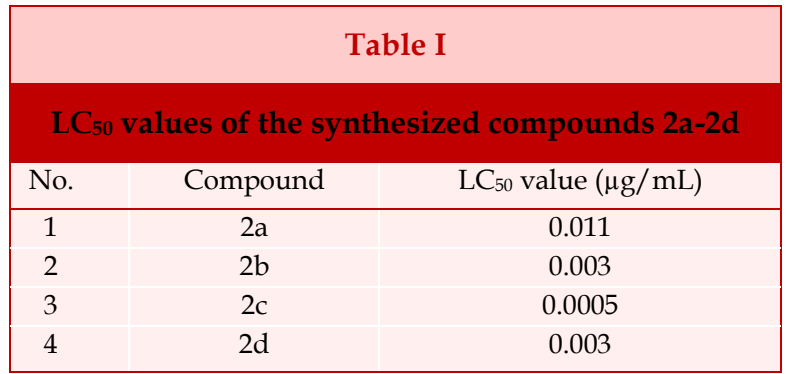

$\left.4 \mathrm{H}, 2 \mathrm{CH}_{2}\right) \delta$ 0.9-0.8 (t, $\left.6 \mathrm{H}, 2 \mathrm{CH}_{3}\right)$. Elemental analysis: the molecular formula of the compound $2 \mathrm{~d}$ is $\mathrm{C}_{24} \mathrm{H}_{20} \mathrm{~N}_{2} \mathrm{O}_{3}$. The found value of $\mathrm{C}=75.0, \mathrm{H}=5.21, \mathrm{~N}=$ 7.28 whereas the calculated value is $\mathrm{C}=75.0, \mathrm{H}=5.20, \mathrm{~N}$ $=7.28$. From the microanalysis result the rest $12.5 \%$ is due to oxygen atom. On the other hand, the actual calculation of $\% \mathrm{O}=12.5$. So, the structure is consistent with the elemental analysis.

The cytotoxicity study of the synthesized compounds was investigated on the brine shrimp as a test organism and the $\mathrm{LC}_{50}$ values for the synthesized compounds are shown in Table I.

\section{Structure activity relationship (SAR)}

The $\mathrm{LC}_{50}$ values shows that it follows the order $2 \mathrm{c}>\mathbf{2 d} \approx$ $\mathbf{2 d}>\mathbf{2 a}$ (Scheme 2). The product $2 \mathrm{c}$ having bromine in seven position in the benzene ring shows highest cytotoxicity among the series. The product with $\mathrm{Cl}$ atom at position 5 in the benzene ring is almost equivalent to product $2 \mathrm{~d}$ having $-\mathrm{C}_{2} \mathrm{H}_{5}$ in position seven of the benzene ring. Unsubstituted product 2a has least cytotoxic effect on brine shrimp.

\section{Discussion}

The furan inserted products $(\mathbf{2 a}, \mathbf{2 b}, \mathbf{2 c}, \mathbf{2 d})$ have been synthesized from isatin and furan in moderate yields. It is to be noted here that the products having furan moiety has potential cytotoxicity than the corresponding thiophene analogues (Hoque and Islam, 2008) in every cases (Scheme 3). This cytotoxicity enhancement is caused by the presence of $\mathrm{O}$ atom in furan ring because $\mathrm{O}$ is more electronegative than $\mathrm{S}$ atom in thiophene ring.

The SAR study of the synthesized compounds showed different cytotoxicity against brine shrimp. The chemical structure of a compound is very important as the relatively minor modification in the compound may result in major change in biological properties. The isatin (1a), 5-chloroisatin (1b), 7-bromoisatin (1c) shows moderately cytotoxicity (Hoque and Islam, 2008) as 1c> $1 \mathrm{~b}>1 \mathrm{a}$ whereas the inserted furan moiety products show higher cytotoxicity. The cytotoxicity enhancement is due to presence of hetero atom $\mathbf{O}$ in the furan ring. The present study shows that the cytotoxicity increases 
by the introduction of $\mathrm{Br}$ atom in the benzene ring than that of $\mathrm{Cl}$ atom and the cytotoxicity is increased by the insertion of furan ring between two isatin molecules than that of thiophene insertion products. So the furan moieties have better cytotoxicity which means, it hinders the replication of DNA molecule more effectively.

\section{Acknowledgements}

The authors express gratitude and thanks to Prof. T. Nagamatsu, Faculty of Pharmaceuticals Sciences, Okayama University, Japan for supplying furan from Japan. We also thank Mr. A.G.M. Lokman Hossain, Okayama University, Japan for providing us the spectral and microanalysis data.

\section{References}

Bhamaria RP, Deliwala CV. In vitro effect of 1-acyl-4-alkyl-(or aryl)-thiosemicarbazides 1-(5-chlorosalisylidine)-4-alkyl-(or aryl)-thiosemicarbazones and some hydrazones of 5cholorosalisyldehyde against pathogenic bacteria including mycobacterium tuberculosis (H37Rv). Indian J Exp Biol. 1968; 6: 62-63.
Chen H, Rhodes J. Schiff base forming drugs: Mechanism of immune potentiation and therapeutic potential. J Mol Med. 1996; 74: 497-504.

Holla BS, Rao, Shridhara K, Akberali PM. Studies on arylfuran derivatives. Part XI. Synthesis, characterization and biological studies on some mannich base carrying 2,4-dichlorophenylfurfural moiety. Farmacos 2000; 55: 388-44.

Hoque MM, Islam MR. Cytotoxicity study of some indophenines and isatin derivartives. Bangladesh J Pharmacol. 2008; 3: 21-26.

Islam MR, Abedin MJ, Duddeck H. Synthesis of 1-methyl bisdioxopyrolino $[2,3: 2,3: 6,5]$ benzene and its heterocycles via thicarbahydrazone, thiosemicarbazone. J Bangladesh Chem Soc. $1998 ; 1$ : 71-78.

Islam MR, Abedin MJ. Khayer K. Synthesis of some 5-spiro(5'-methylisatin)-4-N-acetyl-2-acetylamino- $\Delta^{2}-1,3,4$-ylisatin3-hydrazino)- $\Delta^{2}-1,3,4$-thiadiazolines. Indian J Chem. 2001; 40B: $240-46$

Meyer BN, Ferringni NR, Putnam JE, Jacobsen LB, Nichols DE, Melaughlin JL. Brine shrimp: A convenient general bioassay for bioactive plant constituent. Plant Med. 1982; 45: 31-34.

Solis PN, Wright CW, Anderson MM, Gupta MP, Phillipson JD. A micorwell cytotoxicity assays, using Artemia salina (brine shrimp). Plant Med. 1993; 59: 250-52. 